\title{
HOLORHYNCHUS (PENTAMERIDA, BRACHIOPODA) IN THE UPPER ORDOVICIAN OF ESTONIA
}

\author{
Linda HINTS
}

Eesti Teaduste Akadeemia Geoloogia Instituut (Institute of Geology, Estonian Academy of Sciences). Estonia pst. 7, EE-0100 Tallinn, Eesti (Estonia)

Presented by D. Kaljo

Received January 14, 1993; accepted March 23, 1993

\begin{abstract}
In Estonia the first finds of the Upper Ordovician index genus Holorhynchus are remarkable because of their stratigraphical position. Holorhynchus sp. occurs in the upper part of the Pirgu Regional Stage corresponding possibly to the Dicellograptus anceps Chronozone. The beds with Holorhynchus are overlain by dolomites with the Elsaella Association and lithologically variable strata with the Streptis Association of the uppermost Ordovician stage in the East Baltic, the Porkuni Regional Stage, which corresponds to the Hirnantian Stage of the other regions. The distribution of the Holorhynchus Association in the East Baltic region coincides presumably with a shorttime regression phase that preceded the terminal Ordovician glacio-eustatic lowering of the sea level.
\end{abstract}

Key words: Holorhynchus Association, biostratigraphy.

The purpose of this paper is to call attention to the first finds of the well-known Upper Ordovician brachiopod genus Holorhynchus in Estonia, the northern East Baltic. These finds add some new information to the late Ordovician brachiopod associations in the Baltic basin and the stratigraphy of the boundary beds of the two uppermost Ordovician stages, Pirgu and Porkuni regional stages.

In the East Baltic the brachiopod genus Holorhynchus Kiaer, 1902 was noted for the first time by Paškevičius in the Lithuanian Ziežmariai, Kauno Vokè, Ukmergè, and Taučionys core sections (Пашкевичюс, 1963, 1968) (Fig. 1). In terms of the lithostratigraphic units the beds with Holorhynchus giganteus Kiaer or Holorhynchus sp. are known as the Taučionys Formation distributed in southern and southeastern Lithuania, eastern Latvia, and the western part of the Pskov District, Russia (Мянниль, 1966; Мянниль et al., 1968; Ульст et al., 1982; Лашков et al., 1984; Nõlvak et al., 1989). Different stratigraphers have considered the formation either as the upper part of the Pirgu or as the lower part of the Porkuni regional stages. Evidently the formation corresponds to the upper part of the Dicellograptus anceps Chronozone (Nõlvak et al., 1989; Mănnil, 1990). In Estonia a possible gap in sedimentation has been recorded on the stratigraphical level of the Taučionys Formation. Some earlier references to the occurrence of Holorhynchus sp. in Estonia (for example by Brenchley \& Cocks, 1982) evidently base on the Lithuanian material. 
In Estonia the genus Holorhynchus was identified recently (in 1991) in the Lassi core (K-39) on Hiiumaa Island (western Estonia; Fig. 1). The incomplete pedicle valve of Holorhynchus sp. (Pl., figs. 1-4) in this core and some supposedly conspecific large thick-shelled fragments in the Külaküla core (K-29) come from the cryptocrystalline nodular limestone $0.75-1.00 \mathrm{~m}$ below the dolomites of the Röa Member (the lowermost member of the Arina Formation; Мянниль \& Рыымусокс, 1984) (Fig. 2). On the mainland of Estonia a fragment of the brachiopod valve probably belonging to Holorhynchus has been found by G. Carden from the topmost Ordovician in the Tartu core.

In the Hiiumaa sections the bioturbated cryptocrystalline nodular limestone intercalating with marls rich in trace fossils (burrows) and containing Holorhynchus sp. of the upper part of the Pirgu Regional Stage has been ascribed tentatively to the Kabala Formation by Suuroja (pers. comm.). The co-occurrence of Holorhynchus sp. or H. giganteus and the specific morphotypes of the chitinozoa Ancyrochitina ancyrea in the upper part of the Pirgu Stage in the Lassi core and in the Taučionys Formation in the southern East Baltic sections indicate the existence of temporal analogues of the last formation and Holorhynchus Association at least in some places in Estonia.

In the Estonian sections the succession of the late Pirguan and Porkunian faunas can be observed beginning from the level of the appearance of Holorhynchus. In the Lithuanian and Latvian sections the Holorhynchus bearing Taučionys Formation is known first of all as the topmost fossiliferous part of the Ordovician overlain by barren oolitic limestones (Мянниль et al., 1968; Ульст et al., 1982). Earlier three ecologically different late Ordovician brachiopod associations - the Holorhynchus, Streptis, and Hirnantia associations - have been mentioned in the East Baltic (named as biofacies in Мянниль, 1966; fauna in Хинтс, 1986; communities in Kaljo et al., 1988). The first two are comparable with the associations established by Brenchley \& Cocks (1982) in Norway. The last association is used here in a wider sense according to the term "Hirnantia fauna" of Rong Jia-yu \& Harper (1988). Provisionally these associations were considered as contemporaneous (Пашкевичюс, 1963; Мянниль, 1966; Brenchley \& Cocks, 1982).

The time-responsive succession of the Holorhynchus and Streptis associations has ensued from the stratigraphical position of the Taučionys and Ärina formations in the Ordovician stratigraphical correlation chart (Мянниль, 1987). The finds of Holorhynchus sp. in the Hiiumaa sections confirm this point of view. Moreover, in Estonia the strata with Holorhynchus are separated from the lithologically variable deposits of the Porkuni Regional Stage with the Streptis Association by the dolomites of the Röa Member of the Ärina Formation containing a specific association of brachiopods. The full list of fossils of the last member is given by Rõõmusoks (Рыымусокс, 1991). In core sections the Röa Member is characterized first of all by Elsaella bekkeri (Rosenstein) and Thaerodonta sp. The former represents a convenient nominal genus for a new association - the Elsaella Association succeeding the Holorhynchus and preceding the Streptis Association. In the Lithuanian Ukmergè core (depth 498.95 and $499.6 \mathrm{~m}$; Хинтс, 1975, p. 81; see also Мянниль et al., 1968, fig. 12) Elsaella cf. bekkeri occurs on the same stratigraphical level - above the strata with Holorhynchus.

The data on the occurrence of Elsaella below the strata with Holorhynchus seem to be questionable, particularly of Elsaella bekkeri (Rosenstein) in the Rõusa core (Central Estonia) and E. cf. bekkeri in the Ukmergè core, at a depth of $507.1 \mathrm{~m}$ (Хинтс, 1975, p. 81). Unfortunately, the first core is destroyed and the provisional interpretation of the litho- 
stratigraphical units cannot be checked. The Ukmergè specimen comes from the beds occurring obviously in a wrong place in the core as suggested by the succession of chitinozoans in the beds immediately below the Taučionys Formation (int. 506-508 m; Нылвак, 1988).

By Paškevičius (pers. comm.; see also Мянниль, 1987, p. 32) some southern East Baltic sections have shown the intercalation of beds with the uppermost finds of Holorhynchus and the lowermost elements of the Hirnantia Association (s.1.). In most of the studied sections the Holorhynchus Association seems to be older than the Hirnantia Association. For example, in the Ilijnskoje core the zonal chitinozoan for the PirguPorkuni (in the East Baltic) and Jerrestad-Hirnantian (in Sweden) boundary beds "Conochitina" taugourdeaui Eisenack occurs immediately above the highest finds of Holorhynchus sp. (Nõlvak et al., 1989; Nõlvak \& Grahn, in press).

Following the view of Rõomusoks (Рыымусокс, 1991) about the late Pirguan age of the Röa dolomites, the Holorhynchus Association from the underlying deposits has in Estonia naturally the same age. So, the distribution of Holorhynchus in the East Baltic in general supports the conclusion of Rong Jia-yu \& Harper (1988) about the pre-Hirnantian age of the Holorhynchus Association. A possible exception from Lithuania has been mentioned before. Still, we should note that the lower boundary of the Röa dolomites marked by pyritized discontinuity is more distinct than the upper boundary in about 10 sections studied on Hiiumaa Island. In some publications the Röa Member is considered entirely as the lower part of the Porkuni Regional Stage (Мянниль, 1987; Kaljo et al., 1988). The question concerning the boundary between Pirgu and Porkuni stages will presumably be understood more unambiguously only after the lower boundary stratotype of the last stage is established.

Some stratigraphical complications arise in case of the Kabala Formation (= Aiamaa Formation in Мянниль, 1987; Männil, 1990). In some publications the whole Kabala Formation or its upper part is included within the Porkuni Stage (Мянниль, 1987; Kaljo, 1984; Kaljo et al., 1988; Männil, 1990). If the Holorhynchus bearing strata in the Hiiumaa sections really represent the analogues of the Kabala Formation in Central Estonia, then supposedly the last formation is at least partly of Pirguan age and its upper boundary may be diachronous.

In the Baltoscandian region the Holorhynchus Association is distributed beside the East Baltic in Norway and Sweden (Brenchley \& Cocks, 1982; Jaanusson, 1982). The patchy distribution complicates the establishing of its environmental position. Still, in Norway it is considered as the association of the inner shelf environments (Owen et al., 1990, p. 36). In Estonia it presumably remains within the limits of shallow water environments close to the zone of nonsedimentation. A tendency of gradual sea-level lowering during the late Pirguan time may be suggested (Opacпыльд, 1975). On Hiiumaa Island the studied sections have shown upward increases in the role of trace fossils, the degree of bioturbation, and the amount of the terrigenous material. The taphonomy of Holorhynchus sp. (occurrence of coquina, see Pl., fig. 8), and the distribution of oolitic limestones overlying the Taucionys Formation in the south-eastern East Baltic refer to the same trend (Пашкевичюс, 1962; Лашков \& Яковлева, 1977). The sea-level lowering event on the Pirgu-Porkuni boundary complicates the correlation of the Upper Ordovician deposits in the East Baltic region. Still, it is considerable as an event presumably marking a short-time regression phase preceding the main Ordovician glacio-eustatic sea-level lowering (see Brenchley, 1989).

Finally a short description of the studied pentameroid brachiopod is given. 
Fig. 1. Occurrence of Holorhynchus in Estonia, Latvia (Ульст et al., 1982), Lithuania (Пашкевичюс, 1963, 1968; Лашков et al., 1984), and Pskov district (Nõlvak et al., 1989). 1 - boreholes, the Taučionys Formation or its analogues with Holorhynchus; 2 - the same without Holorhynchus; 3 outer margin of the distribution of the Pirgu Stage (by L. Põlma in manuscript); * data from the descriptions of the sections by L. Põlma.

Fig. 2. A scheme of the texture and description of the Upper Ordovician strata in the Lassi (K-39) core. The texture is marked by argillaceous matter on the bedding planes and stylolite surfaces, also by thin layers. For legend see the description of the section.

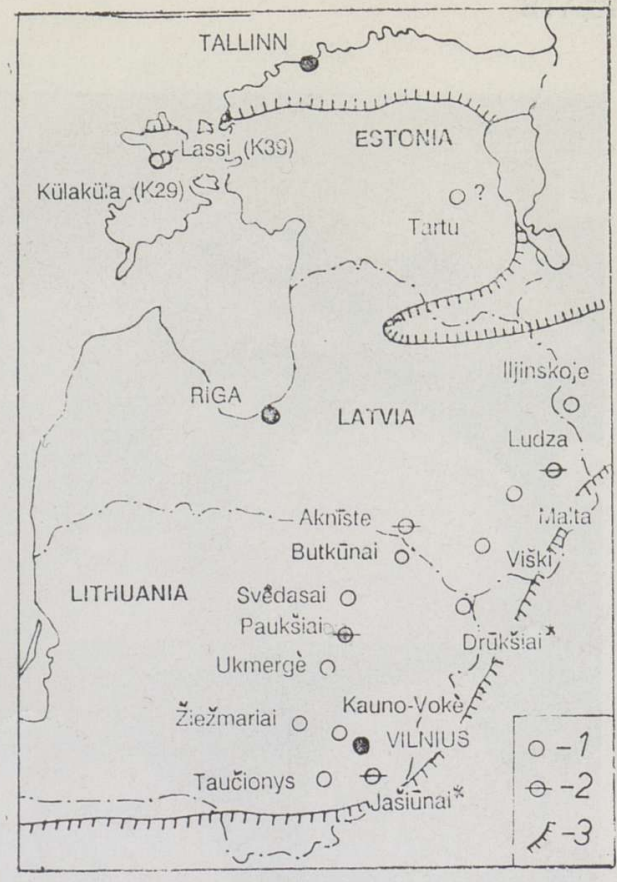

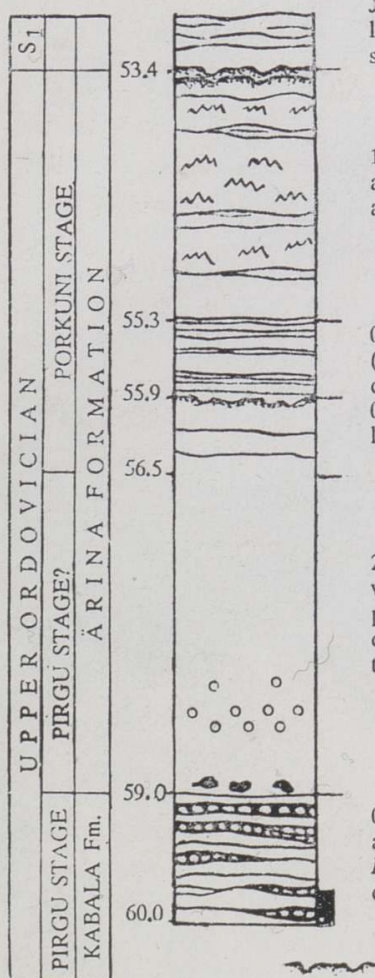

IUURU STAGE, VARBOLA FORMATION, KOIGI MEMBER. Y'ellowish light-gray cryptocrystalline (aphanitic) limestone. A pyritized discontinuity stifface ( 1 , see legend) occurs on the lower boundary.

$1.9 \mathrm{~m}$. TÕREVERE MEMBER. Massive reef limestones with tabulate corals and stylolite surfaces (2), numerous in the mi!dle part. The lower half contains a few thin wavy argillaceous layers (3).

$0.5 \mathrm{~m}$. SIUGE MEMBER. Intcrcalation of dark brown kerogeneous marlstones (4) (ihickness of the layers $1-12 \mathrm{~cm}$ ) and massive light-gray limestones $(5-15$ $\mathrm{cm})$. The lower boundary shows a weakly developed discontinuity curface. $0.6 \mathrm{~m}$. VOHILAID MEMBER. Light-gray massive skeletal limestone. The lower boundary is transitional.

$2.5 \mathrm{~m}$. RÖA MEMBER. Light-gray massive dolomite, the lowermost $25 \mathrm{~cm}$ with dark-gray spots. The lower half is porous. Int. $57.9--58.4 \mathrm{~m}$ contains badly preserved pelmatozoans (5). Close to the lower boundary pyritized carbonate pebbles (6) occur. The lower boundary is lithologically distinct bu the boundary beds are somewhat damaged by drilling.

$0.6 \mathrm{~m}$. Intercalation of pure bioturbated cryptocrystalline (aphanitic) limestone and carbonate marl layers abounding in trace fossils (burrows) (7) Ho!orhynchus sp. comes from the bottom of the core (on the level of black quadrangle).

man 1 man $2=3 \cong 4005$ 


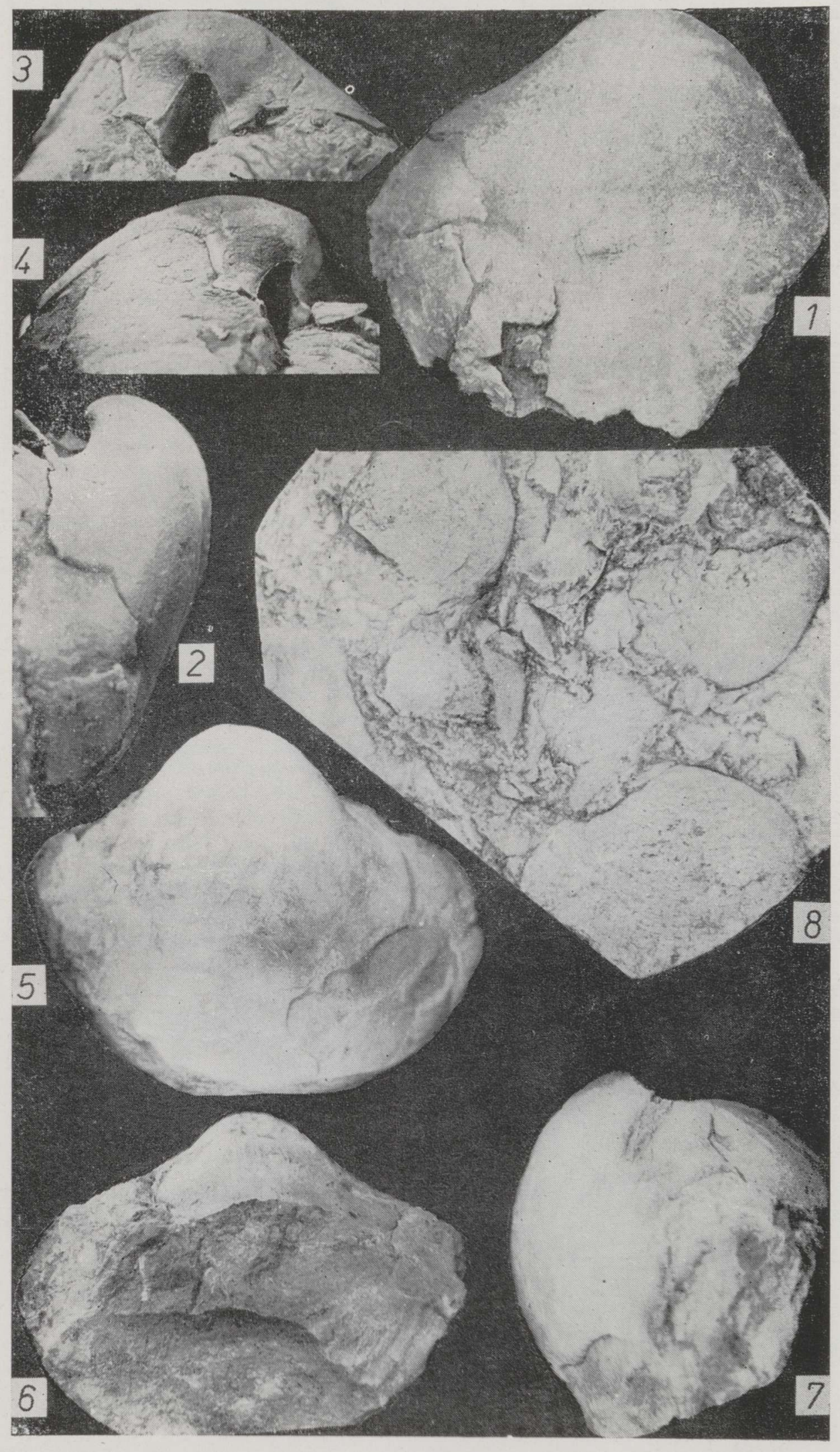


Figs. 1-4. Holorhynchus sp. Pedicle valve $\mathrm{Br}$ 4112. Ventral, lateral, posterior, and postero-lateral views. Western Estonia, Hiiumaa Island, Lassi core (K-39), depth 59.9$90.0 \mathrm{~m}$. Pirgu Regional Stage, Kabala Formation. Collection of the Institute of Geology, Tallinn, Estonia. $\times 1.8$.

Figs. 5-7. Holorhynchus giganteus Kiaer. Complete shell, ventral, lateral, and dorsal views. Eastern Latvia, Malta core, depth $464.7 \mathrm{~m}$. Pirgu Regional Stage, Taučionys Formation. Collection of the Museum of Natural History, Riga, Latvia. $\times 1$.

Fig. 8. Bedding plane with fragments and valves of Holorhynchus sp. Eastern Latvia, Malta core, depth $471.0 \mathrm{~m}$. Pirgu Regional Stage, Taučionys Formation. Collection of the Museum of Natural History, Riga, Latvia. $\times 1.2$.

\section{Holorhynchus sp.}

Pl., figs. $1-4$

Material. Incomplete pedicle valve $\mathrm{Br} 4112$, western Estonia, Hiiumaa Island, Lassi core (K-39), depth 59.9 m, Pirgu Stage.

Description. Pedicle valve small, smooth, flattened in anterior half. Narrow and weak furrow occurs along the mid-line. Ventral umbo incurved, delthyrium open. The hinge teeth are $3 \mathrm{~mm}$ long, developed as pointed processes lenticular in cross-section. Anteriorly spondylium is almost as deep as wide.

Discussion. The described specimen is similar to the Holorhynchus giganteus Kiaer from Norway (Kiaer, 1902; Gauri \& Boucot, 1968) and from Latvia (Pl., figs. 5-7). However, exact identification of one incomplete valve is complicated.

\section{ACKNOWLEDGEMENTS}

The author wishes to thank K. Suuroja for providing a possibility of studying and sampling the Hiiumaa cores, to J. Nõlvak for kindly helping with additional information on chitinozoans. I am thankful to I. Silina from the Museum of Natural History in Riga (Latvia) for her kind permission to examine and use in this paper Latvian material. I am greatly indebted to D. Kaljo and $M$. Rubel for their critical reading of the manuscript. Thanks are due to $A$. Noor for linguistic corrections and to U. Veske and G. Baranov for photos.

\section{REFERENCES}

Brenchley, P. J. 1989. The late Ordovician extinction. - In: Donovan, S. K. (ed.). Mass Extinction: Processes and Evidence. Columbia Univ. Press, New York, 104-132.

Brenchley, P. J. and Cocks, L. R. M. 1982. Ecological associations in a regressive sequence: The Latest Ordovician of the Oslo-Asker District, Norway. - Paleontol., 25, 4, 783-815.

Gauri, K. L. and Boucot A. J. 1968. Shell structure and classification of Pentameracea M'Coy, 1844. - Palaeontographica, 131, A, 79-135.

Jaanusson, V. 1982. The Siljan District. - In: Bruton, D. L and Williams, S. H. (eds.). Field Excursion Guide. IV International Symposium on the Ordovician System. Paleont. Contr. Univ. Oslo, 279, 15-42.

Kaljo, D. 1984. Stratigraphy and lithofacial characteristics. - In: Kaljo, D., Mustjõgi, E. and Zekcer, I. (eds.). Guidebook. Excursions: 027, 028. Intern. Geol. Cong. XXVII session, Tallinn, 8-21.

Kaljo, D., Nestor, H. and Põlma, L. 1988. East Baltic Region. - In: Cocks, L. R. M. and Rickards, R. B. (eds.). A Global Analysis of the Ordovician-Silurian Boundary. Bull. Br. Mus. Hist. (Geol.), 43, 5-7, 85-91.

Kiaer, J. 1902. Etage 5 i Asker ved Kristiania, Studier over den norske Mellemsilur. Norges geol. Unders., 34. 
Männil, R. 1990. The Ordovician of Estonia. - In: Kaljo, D. and Nestor, H. (eds.). Field Meeting Estonia 1990. An Excursion Guidebook. Inst. Geol. Estonian Acad. Sci., Tallinn, $11-20$.

Nõlvak, J. and Grahn, Y. In press, Ordovician chitinozoan biozones from Baltoscandia. Nõlvak, J., Meidla, T., and Hints, L. 1989. The Taučionys Formation (Holorhynchus beds) in the Iljinskoje boring (Pskov district). - Proc. Estonian Acad. Sci. Geol., 38, $2,88-93$.

Owen, A. W., Bruton, D. L., Bockelie, J. F. and Bockelie, T. G. 1990. The Ordovician Successions of the Oslo Region, Norway. Nor. geol. unders. Special Publ., 4, $3-54$.

Rong Jia-yu and Harper, D. A. T. 1988. A global synthesis of the latest Ordovician Hirnantian brachiopod faunas. - Trans. Royal Soc. of Edinburg: Earth Sciences, $79,383-402$.

Лашков Е. М., Яковлева В. И. 1977. Прогноз коллекторских свойств нефтеносных отложений ордовика прибрежной части акватории Балтийского моря. - In: Куршс В. И. (ed.). Литология и полезные ископаемые палеозойских отложений Прибалтики. Зинатне, Рига, 87-96.

Лашков Е. М., Пашкевичюс И. Ю., Сидеравичиене Н. В. 1984. Литостратиграфия ордовикских отложений Средне-Литовского прогиба. - In.: Мянниль Р. М., Менс K. А. (eds.). Стратиграфия древнепалеозойских отложений Прибалтики. АН ЭССР, Таллинн, 77-93.

Мянниль Р. М. 1966. История развития Балтийского бассейна в ордовике. Валгус, Таллинн.

Мянниль Р. М. 1987. Объяснительная записка к стратиграфическим схемам ордовикских отложений. - In: Кальо Д. Л. (еd.). Решения межведомственного стратиграфического совещания по ордовику и силуру Восточно-Европейской платформы. 1984 г., с региональными стратиграфическими схемами. ВСЕГЕИ, Ленинград, $17-57$.

Мянниль Р. М., Пылма Л. Я., Хинтс Л. М. 1968. Стратиграфия вируских и харьюских отложений (ордовик) Средней Прибалтики. - In: Григялис A. A. (ed.). Стратиграфия нижнего палеозоя Прибалтики и корреляция с другими регионами. Минтис, Вильнюс, 81-110.

Мянниль Р. М., Рыымусокс А. Р. 1984. Ревизия литостратиграфической схемы расчленения ордовика Северной Эстонии. - In: Мянниль Р. М., Менс К. А. (eds.). Стратиграфия древнепалеозойских отложений Прибалтики. АН ЭССР, Таллинн, $52-62$.

Нылвак Я. 1988. Хитинозои верхнего ордовика Средне-Литовского прогиба. - Manuscript of ВИНИТИ, № 7811-В88. Москва.

Ораспыльд А. 1975. Литологическая характеристика пиргуского горизонта в Южной Эстонии. - Уч. зап. Тартуск. ун-та, 359. Тр. по геол., VII. Тарту, $14-75$.

Пашкевичюс И. Ю. 1962. К вопросу стратиграфии силурийских отложений по данным глубокого бурения в юго-западной части Литовской CCP. - Lietuvos TSR aukštujų mokyklų mokslo drabai, Geografija ir Geologija, I, 161-172.

Пашкевичюс И. Ю. 1963. Стратиграфическая ревизия силурийских карбонатных отложений Южной Прибалтики. - In: Вопросы геологии Литвы. Ин-т геол. и геогр. АН ЛитССР. Вильнюс, 385-405.

Пашкевичюс И. Ю. 1968. Биостратиграфия и корреляция силурийских терригенных и карбонатных отложений Южной Прибалтики. - In: Григялис А. A. (ed.). Стратиграфия нижнего палеозоя Прибалтики и корреляция с другими регионами. Минтис, Вильнюс, 250-272.

Рыымусокс А. 1991. О стратиграфии и фауне пограничных слоев пиргуского и поркуниского горизонтов в Северной Әстонии. - Уч. зап. Тартуск. ун-та, 934. Töid geoloogia alalt, XII. Eesti ordoviitsiumi paleontoloogia ja stratigraafia. Tartu, 23-35.

Ульст Р. Ж., Гайлите Л. Қ., Яковлева В. И. 1982. Ордовик Латвии. Зинатне, Рига.

Хинтс Л. 1975. Брахиоподы Enteletacea ордовика Прибалтики. АН ЭССР, Таллинн.

Хинтс Л. 1986. Род Streptis (Triplesiidae, Brachiopoda) из ордовика и силура Эстонии. - Изв. АН ЭССР. Геол., 35, 1, 20-26. 


\title{
HOLORHYNCHUS (PENTAMERIDA, BRACHIOPODA) \\ EESTI ÜLEMORDOVIITSIUMIST
}

\section{Linda HINTS}

Käsijalgse Holorhynchus esmasleiud Eesti ülemordoviitsiumist kinnitavad varasemat oletust selle perekonna ilmumisest Balti basseini pirgu ea lõpus. Kahes Hiiumaa puursüdamikus esineb Holorhynchus afaniitses muguljas lubjakivis, umbes $1 \mathrm{~m}$ madalamal Ärina kihistu Röa kihistiku dolomiitidest. Pirgu lademe ülemise osa ja Porkuni lademe iseloomulike käsijalgsete leviku pōhjal on eritletud kolm üksteisele ajaliselt järgnevat assotsiatsiooni - Holorhynchus'e, Elsaella ja Streptis'e assotsiatsioon. Holorhynchus'ega kaasnev kitinosoade koosseis lubab oletada neid sisaldavate kihtide üheaegsust Eestis ja Lõuna-Baltikumis, kus nimetatud käsijalgne on juhtvormiks Taučionyse kihistus. Seega võib esmakordselt tõdeda, et viimase kihistu ajalised analoogid on esindatud ka Eestis, kuigi väga piiratud ulatuses.

Pirgu ja Porkuni lademe piirikihtide litoloogiline iseloom ja oluliste lünkade esinemine piirkonniti viitavad basseini märgatavale madaldumisele. See on tõenäoliselt seotud ühe lühiajalise regressiivse faasiga hilisordoviitsiumi glatsio-eustaatilise meretaseme languse foonil.

\section{HOLORHYNCHUS (PENTAMERIDA, BRACHIOPODA) В ВЕРХНЕМ ОРДОВИКЕ ЭСТОНИИ}

\author{
Линда ХИНТС
}

Первые находки представителей рода Holorhynchus в Эстонии происходят из верхней части пиргуского горизонта, из отложений, подстилающих пачку доломитов низов самой верхней свиты ордовикского разреза. Holorhynchus и сопутствующие им хитинозои подтверждают присутствие аналогов таученской свиты Южной Прибалтики в Эстонии. Раньше предполагалось, что в Северной Прибалтике этой свите соответствует перерыв в осадконакоплении.

В последовательности появления позднепиргуских и поркуниских брахиопод в Северной и Южной Прибалтике выделяются три ассоциации с номинальными родами Holorhynchus, Elsaella и Streptis coответственно, причем последний известен только в Эстонии.

Прерывистость, вплоть до полного выклинивания, отложений с Ноlorhynchus в мелководных фациях Балтийского палеобассейна указывает, по-видимому, на кратковременную регрессивную фазу на фоне позднеордовикского глацио-эвстатического понижения Мирового океана. 